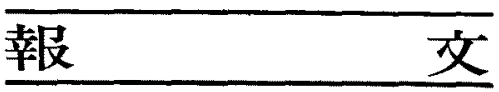

\title{
ポリスチレンの機械的性質と破壊機構について
}

\author{
工業技術院織維高分子材料研究所 中野詔彦 - 長谷川澄子
}

\section{STUDY ON THE RELATION BETWEEN SOME MECHANICAL PROPERTIES AND MECHANISM OF THE FRACTURE OF POLYSTYRENE}

\author{
By Nobuhiko Nakano and Sumiko Hasegawa \\ (Research Institute for Polymers and Textiles, \\ Sawatari 4-1, Kanagawa-ku, Yokohama)
}

The relation between some mechanical properties and mechanism of the fracture of polystyrene has been studied by the morphological observation of the fracture surface when molecular weight, temperature and strain rate have been changed.

The morphology of fracture surface varies with the molecular weight, temperature and strain rate. The area of mirror region becomes larger as the temperature becomes higher and has a maximum value at certain temperature, covering all the fracture surface. The temperature, at which this maximum is observed, is shifted to higher one with the molecular weight of polystyrene and is depressed with lowering the strain rate. The maximum becomes distinct with the molecular weight.

The depression of the tensile strength with the temperature becomes more pronounced with the molecular weight and the strain rate. These tensile strength behaviors are well explained on the basis of the morphological observation on the fracture surface.

The elongation of polystyrene is found to be more closely related with the morphological observation. With the occurrence of crazes, the elongation goes down until it reaches a minimum value, where all the fracture surface becomes the mirror region, i.e., covered with crazes. The effects of temperature, the molecular weight and the strain rate on the elongational behavior are also discussed in terms of the morphological observations.

Summarizing these results, it is found that the tensile strength and the elongation of polystyrene are reasonably correlated with detailed morphological observations on the fracture.

(Received August 23, 1977)

\section{1. 緒言}

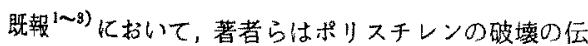
播機構、破壊仙およ代す分子量，温度およびこずみ速度 の影響などについて，主としてモルホロジーの面から究 明した結果を報告してきた。本研究は，それらの結果に もとずき，ポリスチレンの破塄機構の相違により生ずる
機械的性犋の変化を究明するものである。ポリスチレン

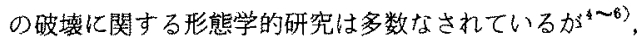
破罣機構之機械的性犋の变化に関する系統的な研究は見 あたらない。こてでは，特に分子量，温度，ひずみ速度 を種々汇変化させたときの延伸破壊強度および伸度と破 面のモルホロジ一の関係を系統的比究明した結果を報告 する。 


\section{2. 実験}

通常の方法 ${ }^{7)}$ に従い、スチレンモノマーをラジカル重 合した。その際, 開始剂濃度等の重合条件を変化させて, 種々の分子量のポリスチレンを合成した。粘度測定から 平均分子量を計算した。表 1 亿示す。粘度測定には, 溶 媒としてトルエンを用い， $30^{\circ} \mathrm{C}$ で行い, $[\eta]=9.2 \times 10^{-5}$ $\times M^{0.72}$ より $\bar{M}_{\mathrm{v}}$ を求めた ${ }^{8)} r M_{\mathrm{w}}=\bar{M}_{\mathrm{v}}$ と仮定した。これ らのポリマーを熱プレス機で $1 \mathrm{~mm}$ の厚さのシート状に 成形し，それから $50 \mathrm{~mm} \times 10 \mathrm{~mm}$ の短冊型にきり出して 試料とした。強伸度測定はテンシロン亚型で行った。破 面の形態観察には, 走査型電子顕微鏡 ( J SMUIII) を用 いた。

Table 1. Intrinsic viscosity $[\eta]$ and weight-average molecular weight $M_{\mathrm{w}}$ of polystyrene.

\begin{tabular}{|c||c|c|c|c|}
\hline Sample & A & B & C & D \\
\hline$[\eta]$ & 0.407 & 0.518 & 0.638 & 0.775 \\
\hline$M_{\mathrm{w}}\left(\times 10^{4}\right)$ & 11.6 & 16.2 & 21.7 & 28.4 \\
\hline
\end{tabular}

\section{3、結果および考察}

\section{1 破面のモルホロジーの変化}

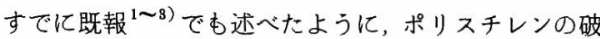
壊の形態を，流動性の観点加ら分類すると，へき開状の 破面を呈する脆性領域，繊維状の破面を呈する延性領域， それらの中間で，粒状の破面を呈するミラ一領域の三種 に大別される。ミラー領域は, クレーズの伝播による破 壊によって生ずる領域で，脆性領域は，クラックの不安 定伝播による破壊によって生ずる領域である。延性領域 は，分子銷あるいはそれらの集団が伸びたりすべったり して破壊した領域である。ただし高分子材料の分子鎖は， 一般にある一群の単位 (セグメント) として動く。既報 ${ }^{1}$ ) に拉いて著者らはポリスチレンの破塄の破 壊の形態観察について報告したが，そのと きの分子銷の局所的配向により発生するク レーズの走査型電子顕微鏡写真でも明らか なように，ポリスチレンの分子鎖は一本一 本ばらばらに流動しないで，集団として流 動しているので，配向してもある一群の束 が配向しているように観察される。従って 低温域においては異なる脆性破壊機構が考 えられる。すなわち同じ弾性限界ひずみ内 の破断でも，本研究におりる脆性破壊はセ グメント間の凍結による脆性破壊である。 極低温にすれば，セグメント内の分子一本 一本の間の涷結が生じ，このときの破壊が
真の脆性破買となる。従ってもっ之温度を低下していけ ばさらに強度が上昇するととになる。本研究の場合には， 低温域での真の脆性破壊については検討していない。ま た板厚と変形温度ひずみ速度などによって同じ脆性破壊 でも異なる機構が考えられる。すなわち平面ひずみ状態と

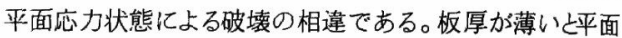
応力状態になり，温度が高くなってもなりやすい。本研究 における板厚では,脆性破壊は全て平面ひずみ状態であっ た。上記三つの破壊機構によって生ずる領域の面積は， 流動性の相違により異なる。流動性が大きくなると延性 領域が增大し，脆性領域が減少する。一般的には，一つ の破面に二つの領域が混在するととが多い。流動度が極 端に小さい場合 (低温あるいは高速度の破壊の場合)に は，全面が脆性領域となる。流動度が増大してくると， ミラー領域と脆性領域が混在してくる。流動度に比例し てミラ一領域の面積が増大し, ある点で全面がミラー領 域となる。さらに流動度が増大すると、、ラー領域と延 性領域が混在し, 最終的には全面が延性領域となってし まう。分子量が小さくなると流動性が増大する。また温 度が高くなったり，ひずみ速度が小さくなっても流動性 が増大する。ただし, 分子量が小さい試料では, ミラー 領域も脆性領域屯全般に起伏が少なくなる。従って流動 度が同じでも破面の様相は分子量により相当異なる。延 性領域においては, 流動度が增大すると, 試料は相当に 延伸され，分子鎖あるいはそれらの集団の配向により， 繊維構造の繊維の長さは短くなる。以下に分子量, 温度， ひずみ速度を変化させたときの走査型電子顕微鏡による 破面の写真の代表例を示す。図 1 は流動性があっとも小 さい試料 Dを $20^{\circ} \mathrm{C}$ で $100 \% / \mathrm{min}$ のひずみ速度で延伸し たときの破面で，ほとんど全面が脆性領域を示している。 図 2 は, 試料 $\mathrm{D} 40^{\circ} \mathrm{C} ， 10 \% / \mathrm{min}$ のびみ速度で延伸 したよきの破面の走査型電子顕微鏡写真である。写真の

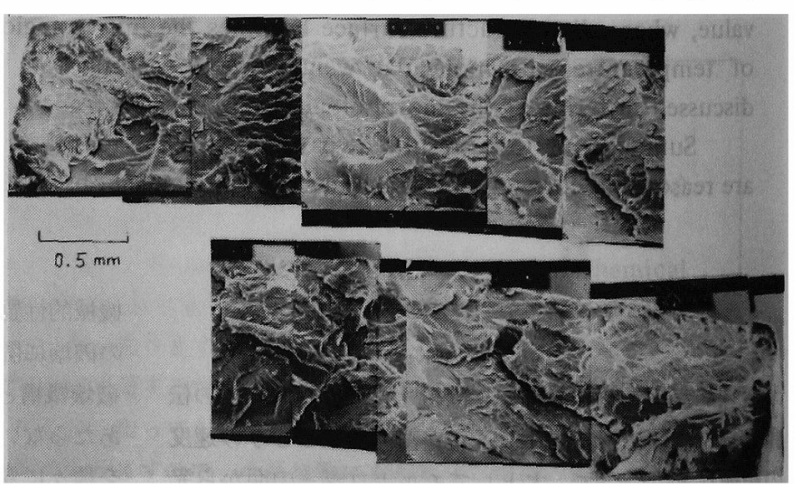

Fig. 1 Scanning electron micrograph of fracture surface of sample $\mathrm{D}$ at $20^{\circ} \mathrm{C}, 100 \% / \mathrm{min}$. 
(35)

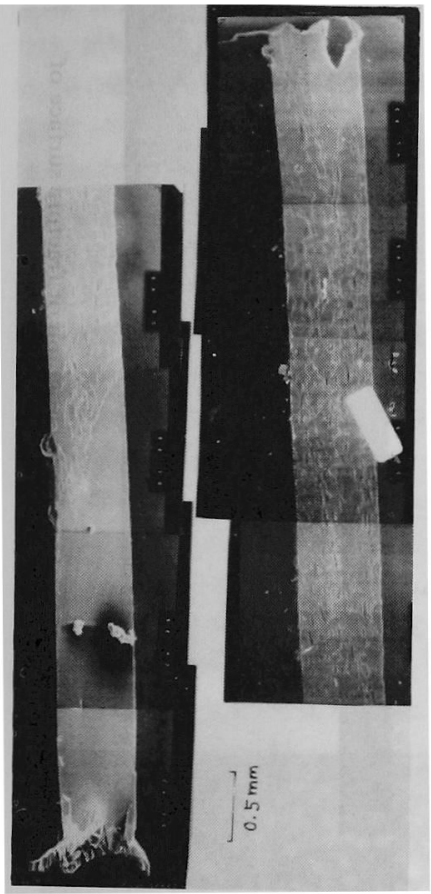

Vol. 34 , No. 7 (1978)

$\mathrm{T}-287$
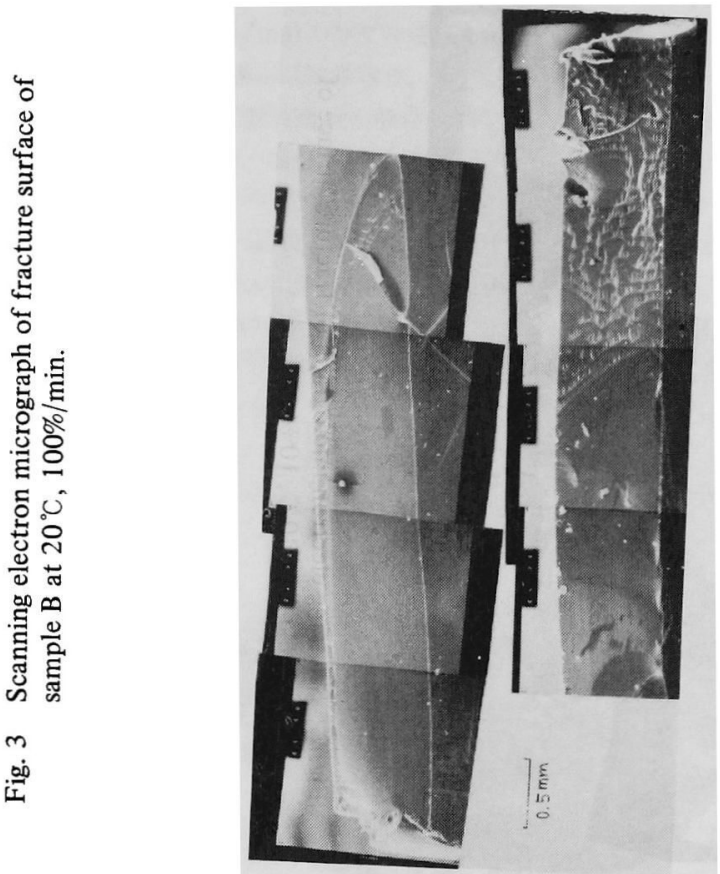

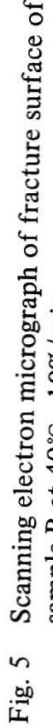

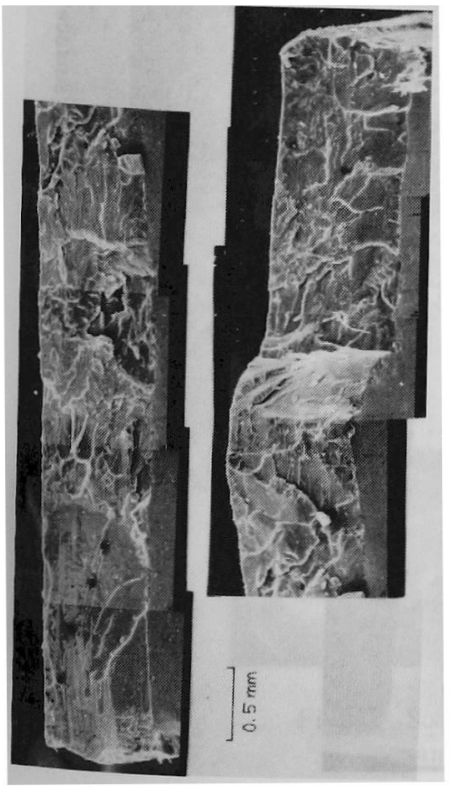

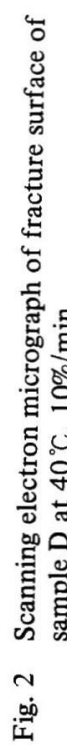

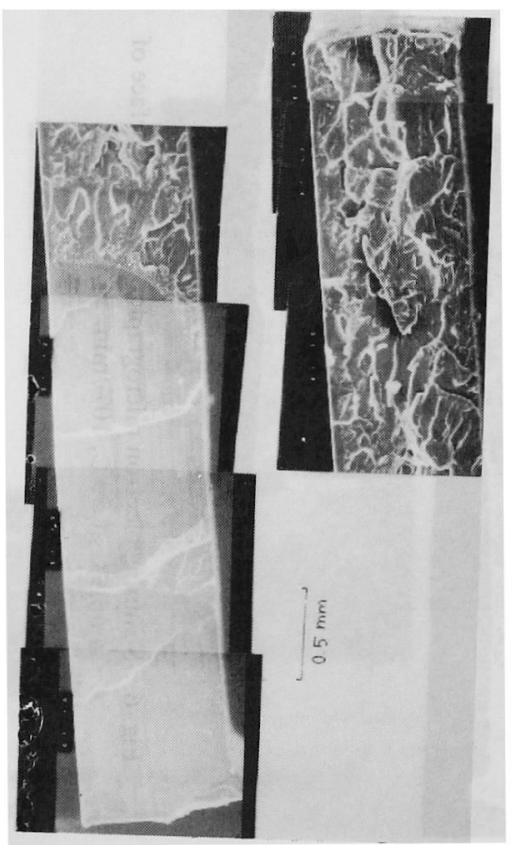

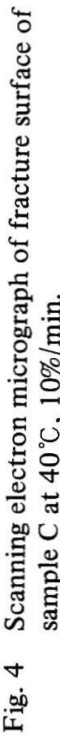



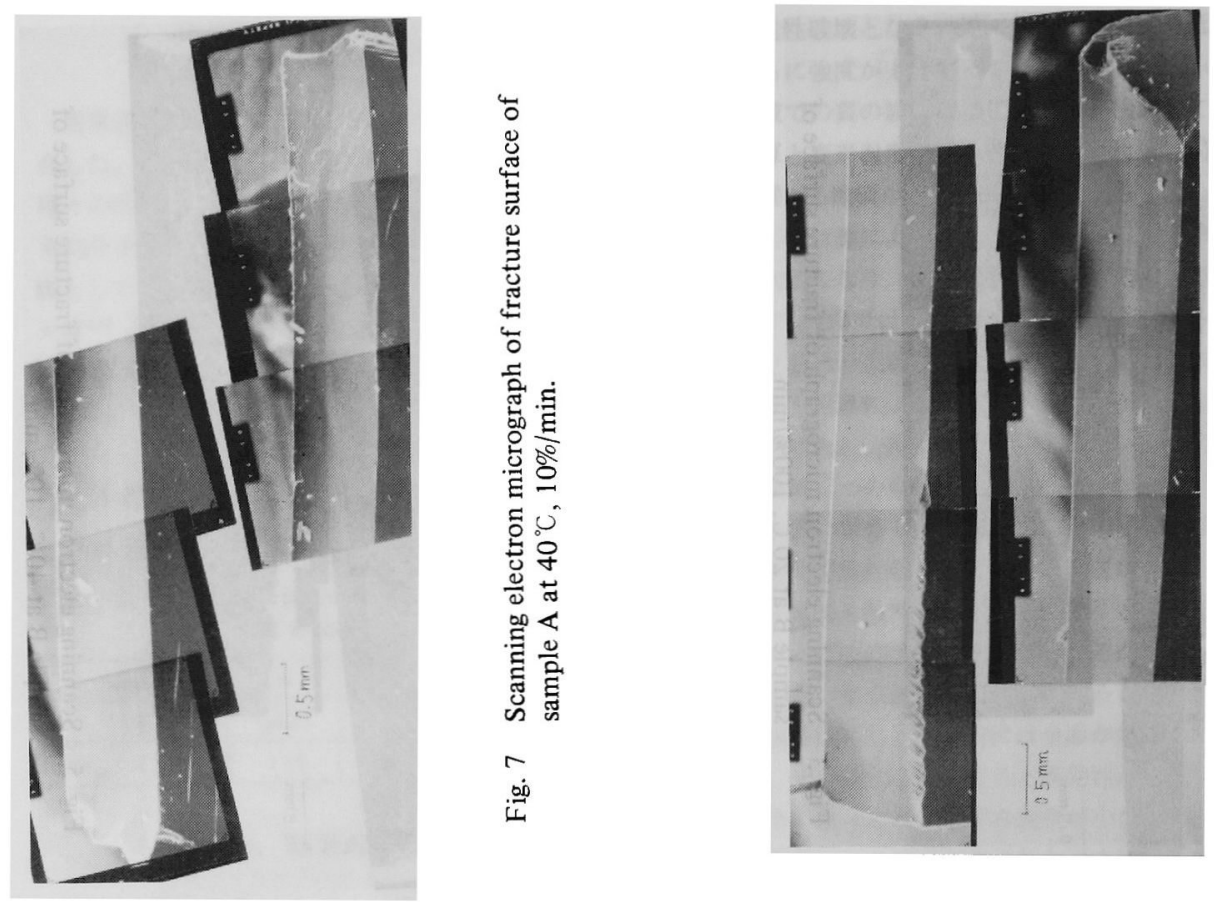

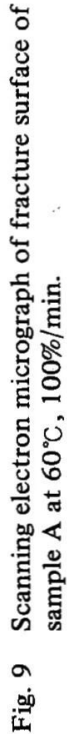

(⿻)

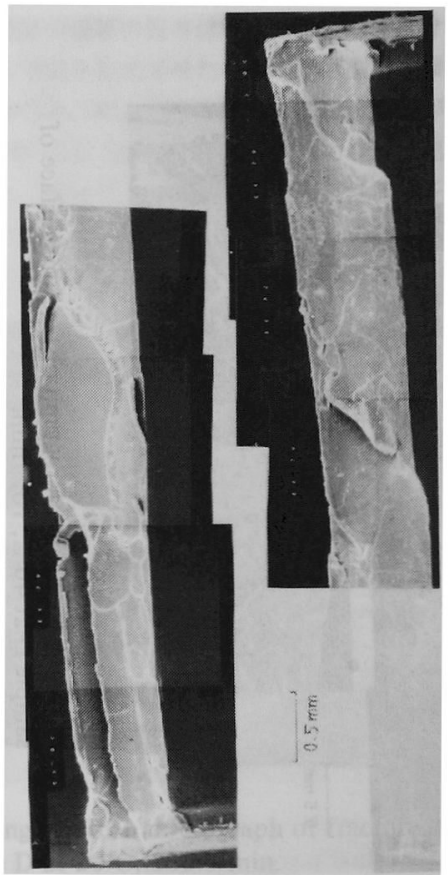

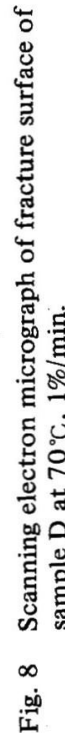


左側飞 $20 \%$ 程度のミラー領域が存在するのがわかる。应 3 は，試料Bを $20^{\circ} \mathrm{C}$ で $100 \% / \mathrm{min}$ の延伸速度で延伸し たときの破面の電顕写真で，ミラー領域の面積が $30 \%$ 程 度になっているのがわかる。図 4 は, 試料 $\mathrm{C}$ を $40^{\circ} \mathrm{C}$ で 10 $\% / \min$ のざみ速度で延伸破壊したときの破面の写真 で, ミラー領域の面積が $50 \%$ 程度になっている。図 5 は, 試料 $\mathrm{B} 40^{\circ} \mathrm{C} て ゙ 10 \% / \mathrm{min} の$ 速度で延伸したときの破面 で、ミラー領域の面皘は70\%程度になっている。図 6 は

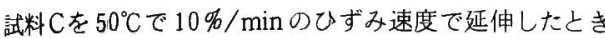
の破面の写真であり，ミラー領域の面積が図 5 の場合と 同じく $70 \%$ 程度である。図 7 は, 試料 $\mathrm{A}$ を $40^{\circ} \mathrm{C}$ で， 10 \%/minのひずみ速度で延伸したときの破面の写真でミ ラー領域の面積が $80 \%$ 程度になっている。図 8 は, 試料 $\mathrm{D} 70^{\circ} \mathrm{C}$ で, $1 \% / \mathrm{min}$ のひずみ速度で延伸した破面の写 真で，全面がミラ一領域となっている。図 9 は, 試料 $\mathrm{A}$ を $60^{\circ} \mathrm{C} て ゙ ， 100 \% / \mathrm{min}$ のひずみ速度で延伸したときの 破面の写真で, やはり全破面がミラ一領域となっている。 ミラー領域の平滑な部分を拡大すると，図 10 亿示すよ

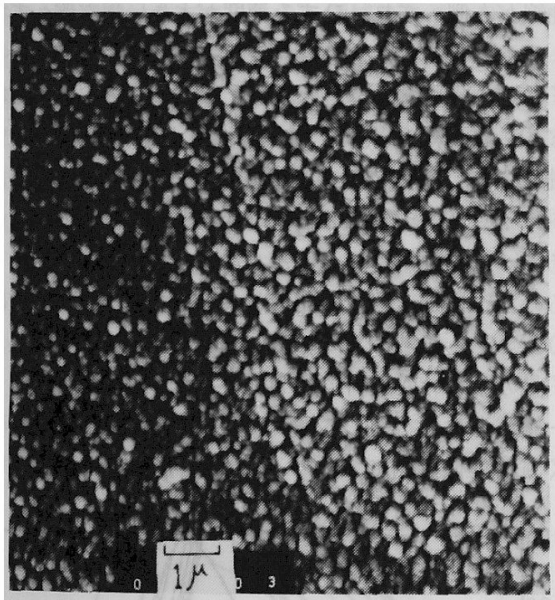

Fig. 10 Scanning electron micrograph of mirror region of fracture surface of sample $\mathrm{A}$ at $60^{\circ} \mathrm{C}, 100 \% / \mathrm{min}$.

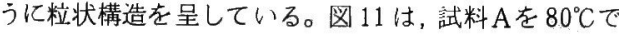
$1 \% / \mathrm{min}$ のひずみ速度で延伸したときの破面の写真で， $80 \%$ が延性領域で， $20 \%$ がミラー領域となっている。 この延性破壊の破面は複雑で，伸びた䋐維構造のために, ミラー領域がかくれてしまって，観察しにくいので，観 察の角度を変化させて拡大すると図 12 に示すように

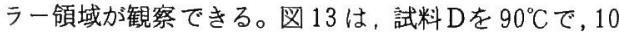
$\% / \mathrm{min}$ のひずみ速度で延伸したときの破面の写真で $90 \%$ 程度が延性領域之なっている。闵 14 は, ミラー領 域之延性領域の境界面の拡大写真である。図 15 は試料 Cを $90^{\circ} \mathrm{C}$ で, $10 \% / \min$ のひずみ速度で延伸したときの 破面の写真で，全面が延性の絨維状領域となっている。 それを拡大したのが，図16で䄉維構造の䄉維の長さが

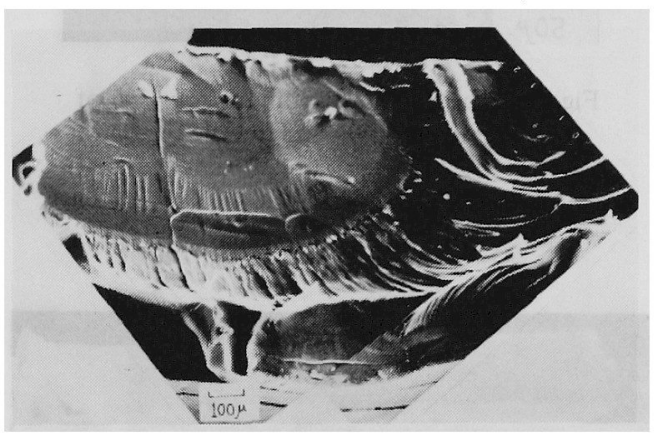

Fig. 12 Scanning electron micrograph of mirror region and ductile region of fracture surface of sample A at $80^{\circ} \mathrm{C}, 1 \% / \mathrm{min}$.

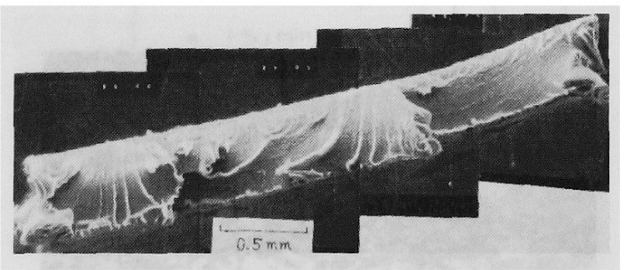

Fig. 13 Scanning electron micrograph of fracture surface of sample D at $90^{\circ} \mathrm{C}, 10 \% / \mathrm{min}$.

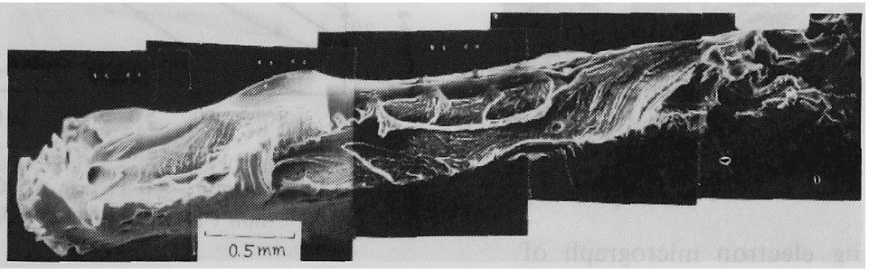

Fig. 11 Scanning electron micrograph of fracture surface of sample $\mathrm{A}$ at $80^{\circ} \mathrm{C}, 1 \% / \mathrm{min}$. 


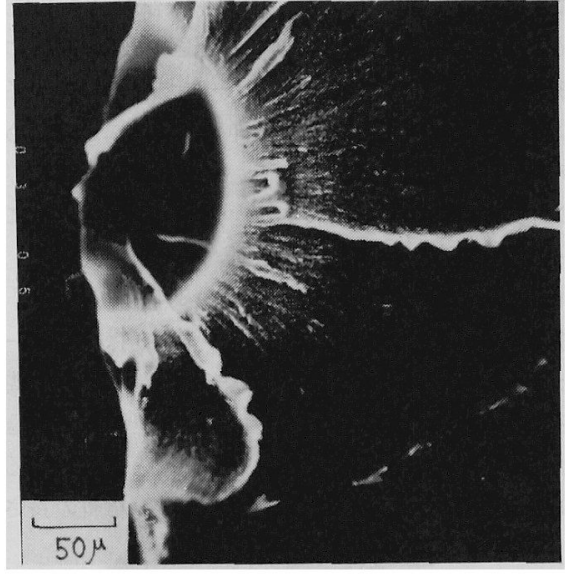

Fig. 14 Scanning electron micrograph of mirror region and ductile region of fracture surface of sample $D$ at $90^{\circ} \mathrm{C}, 10 \% / \mathrm{min}$.

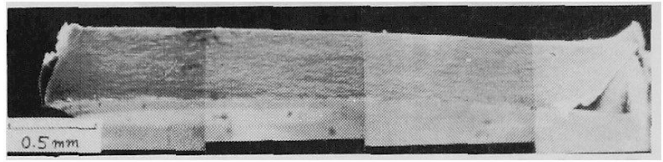

Fig. 15 Scanning electron micrograph of fracture surface of sample $\mathrm{C}$ at $90^{\circ} \mathrm{C}, 10 \% / \mathrm{min}$.

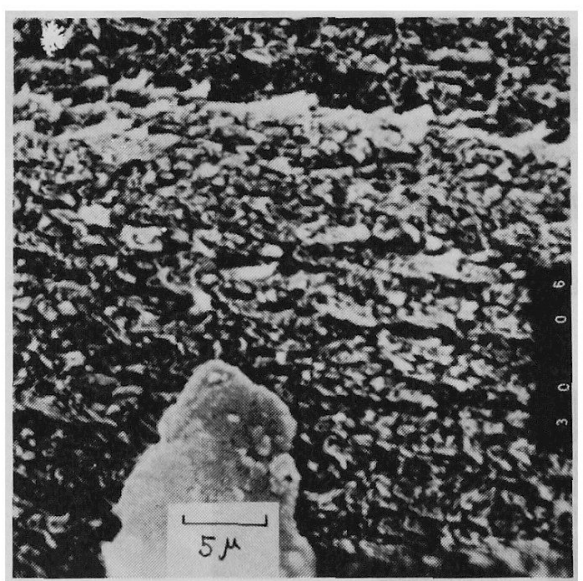

Fig. 16 Scanning electron micrograph of fibrous structures of ductile region of fracture surface of sample $\mathrm{C}$ at $90^{\circ} \mathrm{C}, 10 \% / \mathrm{min}$.
短くなっているのがわかる。以上，破面の変化の代表例 を示したが，次に貱面の变化を定量的に、系統的に考察 する。

\section{2 破面の変化の定量的考察}

分子量，温度，ひずみ速度を変化させると，破壊機構 が変化して破面のモルホロジーも変化するととは前にも 述べたが，それらの変化を定量的に検討する。図 17 は 分子量，ひずみ速度を变化させた試料の温度とミラ一領 域の面積の比率の関係を示したあのである。破面のモル ホロジーは, 低温側ではミラー領域之脆性領域が混在し ている。したがって，ミラー領域の面積が 10\%のとき は，脆性領域が90\%であることを示す。一方，高温側 においては, ミラー領域と延性領域が混在している。し たがって, ミラ一領域の面積が $10 \%$ の之は, 延性領 域の面積が $90 \%$ であるととを示している。すなわち， 図において，左上隅が脆性領域を示し，中間の曲線内が ミラー領域であるととを示し，右上隅が延性領域である ことを示す。分子量が大きい試料程，ミラ一領域の面積 の曲線が右側へずれ，ひずみ速度が大きい程右側へずれ る。また分子量が大きい程，ひずみ速度の影響が大きく， 分子量が小さくなるにしたがってひずみ速度の影響はな くなる。D試料の場合, $100 \% / \mathrm{min}$ と $1 \% / \mathrm{min}$ のひず み速度では, 温度にして $10^{\circ} \mathrm{C}$ 程度の変化があるが, $\mathrm{A}$ 試料では， $100 \% / \mathrm{min}$ と $1 \% / \mathrm{min}$ とではほとんど同じ である。低分子量になるほど，クレーズが発生しやすく なるので，ミラー領域の面積が大きくなる。D試料では $100 \%$ ミラー領域になるのは，ほとんど一点であるが， 分子量の小さい $\mathrm{A}$ 試料では $50^{\circ} \mathrm{C} \sim 70^{\circ} \mathrm{C}$ の間で, $100 \%$ ミ ラ一領域となる。そして極大を示す温度は, 分子量が小 さくなる程低温側にずれる。なお，分子量が 10 万以下に

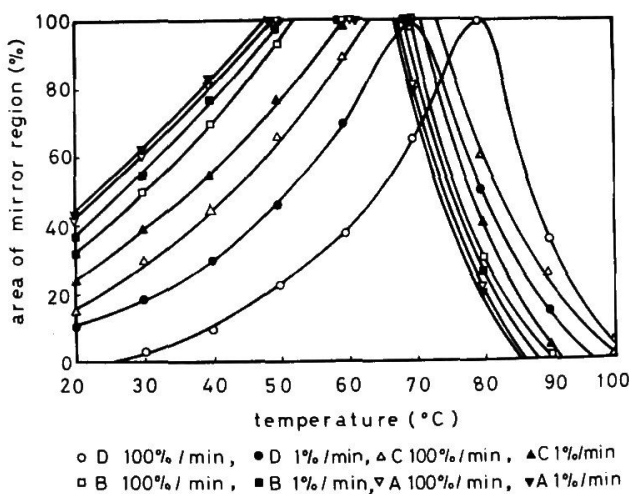

Fig. 17 Relation between the temperature and the area of mirror region of fracture surface for polystyrenes. 


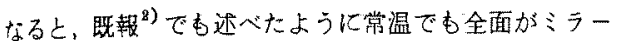
領域になってしまう。これら破面の形態変化すなわち破 境機構の変化が機械的性質に大きな影響を与えると思わ れる。

\section{3 機械的性诈の変化}

次に，分子量，鼬度㧍よびひずみ速度を変化させだ きの機槭的性質の変化を検討し, 破面のモルホロジーの 変化之の関連を明ら加江る。图 18 は，各分子量の試 料の温度と引脹强度の関係を示したあのである。分子量 の高い口試料では，温度の增大とともに引張強度が急激 に低下している。これは，図 17 で示した急激なミラー領

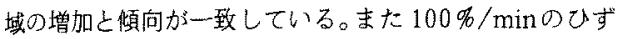

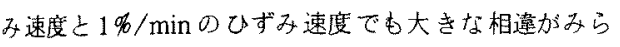
れるが，この相違も，図17の大きな相違の煩问上一致す る。そして，分子量怔低下する，ひずみ速度の相違に よる引張强度の相違も小さくなってくる。B試料，A試 料になると，はとんどひずみ速度の相違による翌化はみ られない。また引張強度の低下李緩やかになってくる。 しれらの結果はすべて，ミラー頒域の面積の変化の傾问 と一致する。すないち引張強度は，あきらかに破壤の機 棈之密接な関係をもっている。次に㵋度と伸び率の変化 について検討する。図19〜22に各試料のひずみ速度を 変化させたときの温度と伸じ率の関係を示した。各試料 ともある温度で，伸び率が極小になる。この極小点は、

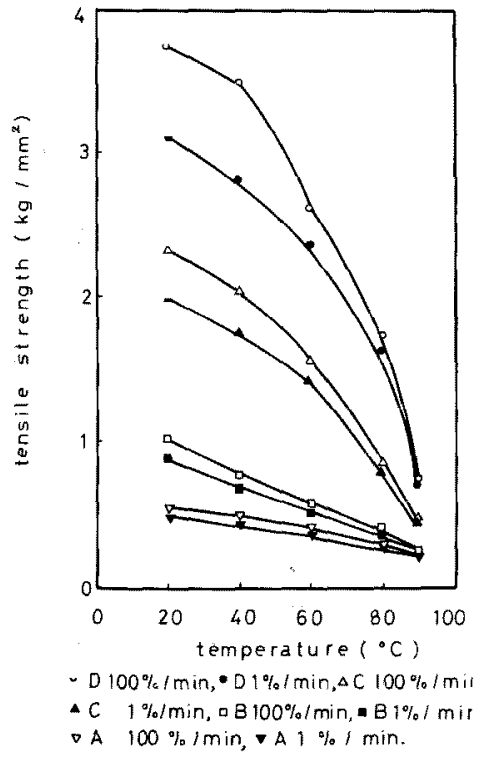

Fig. 18 Relation between the temperature and the tensile strength for polystyrenes.
図17亿示す全破面がミラー頷域になる点よ一致する。 D試料のように，極小点がはっきりしている場合には， 全破面がミラー湎域しなる点もはっきりしている。A試 料の上うに分子量が小さい試料で，全破面がミラー領

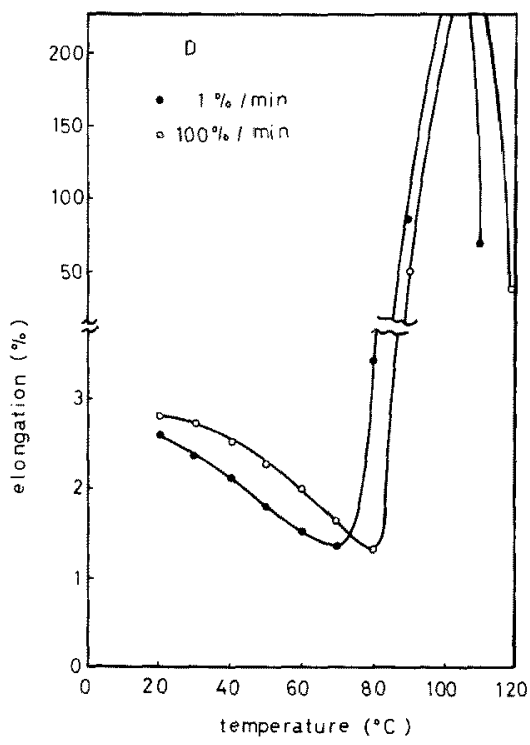

Fig. 19 Relation between the temperature and the elongation for sample D.

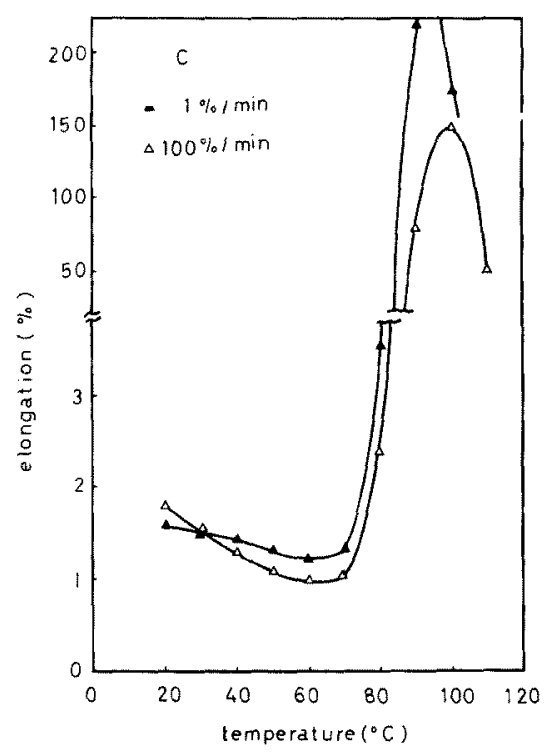

Fig. 20 Relation between the temperature and the elongation for sample $C$. 


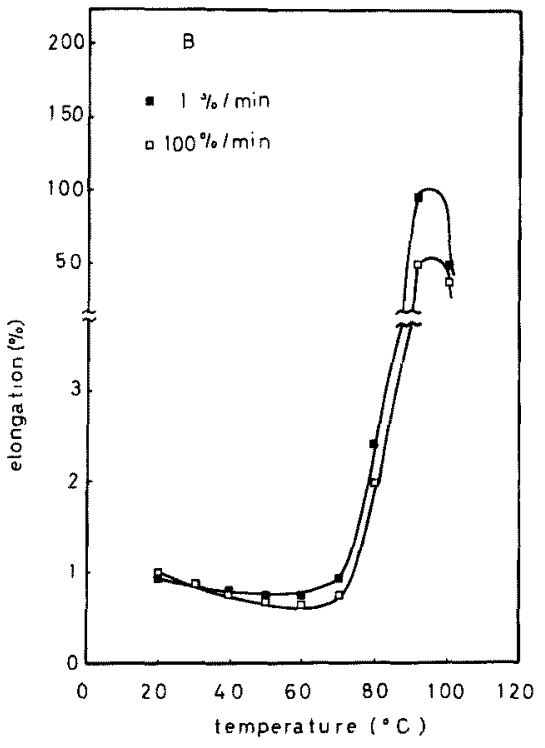

Fig. 21 Relation between the temperature and the elongation for sample $B$.

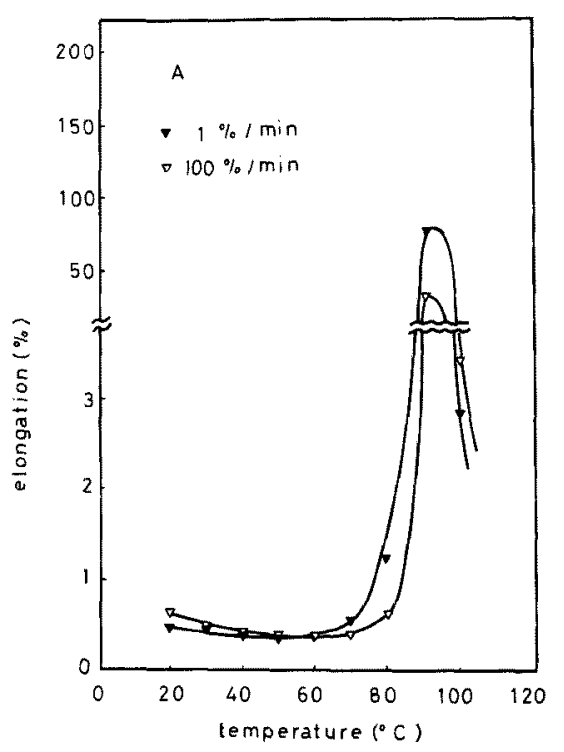

Fig. 22 Relation between the temperature and the elongation for sample $\mathrm{A}$.

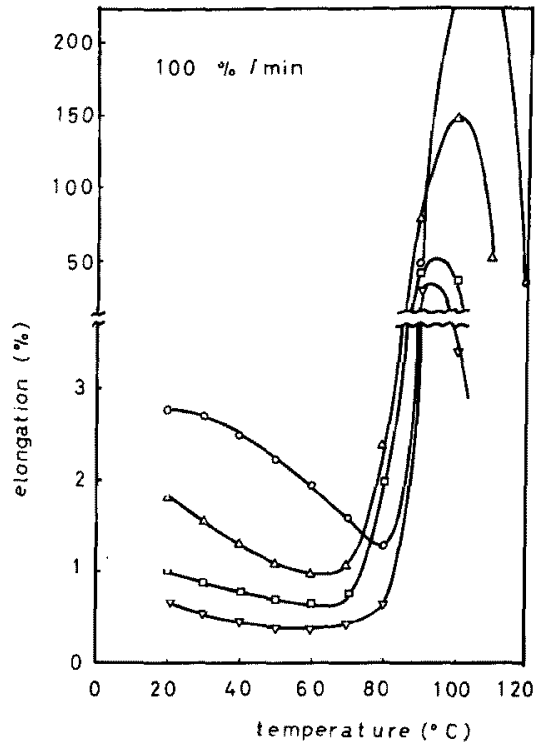

Fig. 23 Relation between the temperature and the elongation for each sample at $100 \% / \mathrm{min}$.

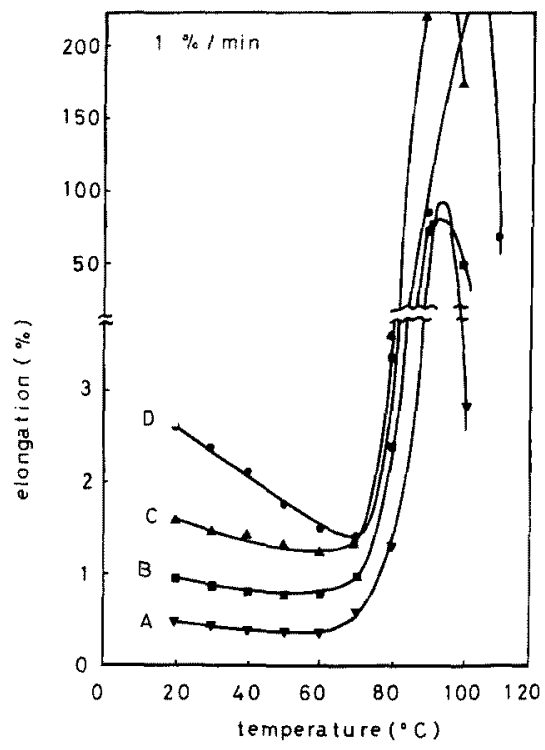

Fig. 24 Relation between the temperature and the elongation for each sample at $1 \% / \mathrm{min}$. 
域になる温度にある幅があるが，伸び率の極小温度にも 幅がみられる。またひずみ速度が小さくなると，低温 测侸小点が移動するが，分子量が小さい試料では，ひ ずみ速度にはとんど影暳されなくなる。これらの点も， 沺 17 のミラー領域の面皘の変化の傾向と一致している。 图23および24は，100\%/minおよび1\%/minのひず み速度のときの备試料の温度と伸び率の関係を示したも のである。ともに分子量が大きい程，高温側に極小点が あり，分子量が小さくなると低温側化極小点が移動し， 極小の底の部分がひろくなってくるのがわかる。以上の 事実はすべて，ミラー領域の面棈の变化の傾向之一致す る。そして，ミラ一領域の面積の増大に従い，伸ご率が 低下するととがわかる。すなわち、クレーズの任播によ る破壤機構仙より伸び率が低下する。破㯰強度よりも， 伸び率の方がより密接に破壊機構に関係しているこよが 明らかになった。

\section{4 破壊機構の変化と機械的性变の変化の関係} 以上の結果にもとずき，破壊機構の变化之機械的性梊 の変化の関係を図式的に検討する。とくに関連の深い， 伸び率について検討する。図25は，試料D，Cおよび Aについて温度と伸び率の関保を闵式的に示したもので ある。実線で示した曲線は，クレーズが発生しないで皮 壊したと仮定したときの曲線で，破線で示したものは， 夷祭の場合で，クレーズが発生して破壊したときの曲線

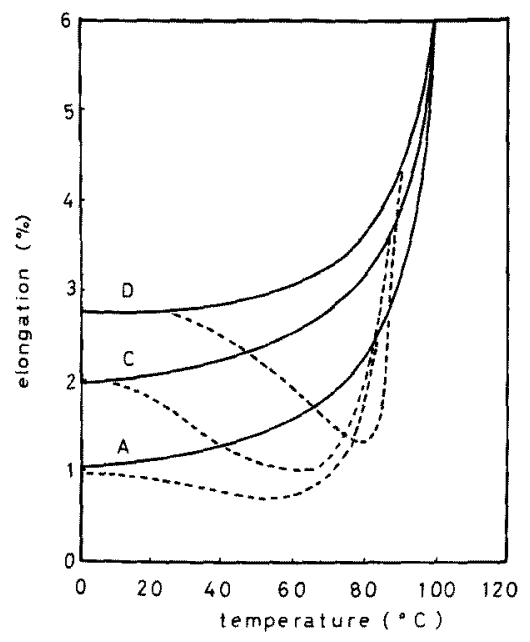

Fig, 25 Model curves of relationship between temperature and elongation for sample D, C, A. Solid lines indicate the model curves in the case of no crazing. Broken lines indicate the real curves in the case of occurring the craze.
である。高任下などのタレーズが発生しない条件で破壊 すると，図に示さ机るうにポリスチレンでも，伸び率 は温度の上杽とと屯に增大するはずである。しかし，常 代におけるポリスチレンでは，セグメントの局部的な伸 びあるいはすへりにより、クレーズが発生しやすい。ク レーズが発生すると，そこから破壊が伝播し全体の伸び が低下する。クレーズが発生しやすい材料では，温度の 上昇とともにクレーズが增大し(ミラ一領域の面皘が增 大し)，伸び率が咸少する。そして全面がクレーズによ る破壊を示す温度，すなわち全破面がミラー領域となる 温度では，伸び辣は極小を示す。そして延性破壊が生ず る混度になると伸び率は再び鼬度とともに上昇する。そ して図に示すように，分子量が大きい試料では，七グメ ントのからみ合いが強いため，極小点估高温にあり，分 子量が小さい試料では，極小点は低温側に移り，クレ一 ズ登生に対する抵抗力が小さいので，その温度偪はひろ くなる。しかし分子量の小さい試料では，もともと破壊 に対する抵抗力が小さいので，クレーズ発生による機械 的性質の低下は分子量の大きい試料はどではない。

\section{4. 結論}

ポリスチレンの分子量，温度およびひずみ速度を変化 させたときの延伸破蕒強度上伸び率上破面のモルホロシ 一の関係を系統的検討し，ポリスチレンの破壤機構の 相違により生ずる機械的性質の変化を追求した結果，次 の事が明らかになった。

破面のモルホロジーは，分子量，温度执よびひずみ速 度の大小によりそれぞれ異なる。ミラ一頒域の面積は温 度の上昇とともに增大し，ある温度て極大となり，全面 がミラ一頒域さなり，温度の上昇とともに減少する。そ の極大温度は，分子量が大きい程高温側にあり，ひずみ 速度の低下とと6に低温僛に移る。分子量が小さくなる と極大温度は低温側に移るが，ひずみ速度の影䈏は小さ くなる。分子量が大きい程極大点はシャープにあらわれ る。破填強度は温度の上昇に上り低下するが，分子量が 大きい程その候向は急激になり，ひずみ速度の影響が大 きくなる。この結果はモルホロジーの結果と一致する。 伸び率の変化は，さらにモルホロジーの変化上密接な関 係にある。伸び率はクレーズの発生ととあに低下し，全 面がミラー領域となる温度では極小上なる。伸び率の変 化は，ミラー領域の面積の変化と全く问等である。これ らの事加ら，機械的性犋の変化は，破壞機構の変化上密 接な関係にあることが明らかになっだ。

付記：本研究にあたり，指導を得た当所福多健二材料 工学研究室長に深謝します。なお，本研究は，第 7 回繊 維連合研究発表会 (昭和 50 年 10 月，大阪）で発表した。 


\section{文献}

1) 中野, 岸野；繊学誌，29，T-96(1973)

2) 中野; 擮学范, $\mathbf{3 1}, T-143(1975)$

3) 中野, 長谷川; 繊学誌, 32, T-254 (1976)

4) B. J. Bird, G. Rooney and J. Mann; Polymer, 12, 742 (1971)

5) B. L. Earl, R. J. Loneragan, J. Markham and M. Crook; J. App. Polymer. Sci., 18, 245
(1974)

6) J. Murray and D. Hull; J. Poly. Sci. A-2, 8, $583(1970)$

7) 藤井、須本；スチロール樹脂，日刊工業新聞社 (1961)

8) T. Alfrey, A. Bartovics and H. Mark; J.Am. Chem. Soc., 65, 2319 (1943)

日本化学会綸「实験化学講座」第 8 卷 (上) 第 5 章, 丸普 $(1965)$ 